\title{
Snow Ecology: An Interdisciplinary Examination of Snow-Covered Ecosystems
}

Edited by H. G. Jones, J. W. Pomeroy, D. A. Walker, and R. W. Hoham. 2001. Cambridge University Press, New York. $\mathrm{xx}+378$ pp., illus. U.S. \$80.

As its title suggests, Snow Ecology examines snow and its effects from many points of view. The book is divided into seven multi-authored chapters or review papers. The chapter titles provide a good summary of the entire book: Snow Cover and the Climate System, Physical Properties of Snow, The Chemistry of Snow: Processes and Nutrient Cycling, Microbial Ecology of Snow and Freshwater Ice with Emphasis on Snow Algae, The Effect of Snow Cover on Small Animals, Snow-Vegetation Interactions in Tundra Environments, Tree-ring Dating of Past Snow Regimes.

Given the wide range of topics covered the book is best viewed as a reference book or textbook rather than something to sit down to read from cover to cover. To this end the book includes a very comprehensive table of contents ( 5 pages). This allows the reader to easily locate a topic within a chapter. In addition, there is a 20-page glossary of terms and a fairly thorough index. I was also impressed that most chapters concluded with suggestions for future research needs, although not all chapters explicitly listed this as topic in the table of contents. The book is profusely illustrated with black-and-white drawings and graphs. There are four pages (two sheets of glossy paper) with colour illustrations that added little to the quality of the book but one wonders what effect they had on the cost.

It should be stressed that this book's emphasis is on snow, not winter. Hence there is only one slender chapter on animals and this is focused on winter active invertebrates and small mammals. Topics such as hibernation, or adaptations in birds or large mammals to winter conditions are beyond the scope of the book. This is not a criticism, as the editors have carefully avoided the broader term winter ecology, but it still might mislead some readers.

Overall, the writing is clear and strong. There is no poetic language here. The statements are fully referenced. While this is not the definitive book on winter ecology it clearly is an excellent guide to snow and how it affects the landscape.

\section{DAVID SEBURN}

Seburn Ecological Services, 920 Mussell Road, RR 1, Oxford Mills, Ontario KOG 1 S0 Canada

\section{Seabirds and Atlantic Canada's Ship-Source Oil Pollution}

By F. Wiese. 2002. World Wildlife Fund, Toronto, Canada. 82 pp., illus.

The public seems to have a love-hate relationship with oil. Oil allows for high salaries and contributes to civilisation, but it also can create severe pollution. As this report shows well, chronic offshore oil ranks among the most severe pollution problems in the world.

"Many people consider Canada to be one of the leading nations in environmental conservation in the world". However, the still conservative estimate of 300,000 dead Canadian seabirds due to chronic oil pollution and presented in this report is shocking, to say the least. Besides a seabird population issue this is also a major animal care issue: over 300000 animal individuals are suffering and are dying a gruesome death. As this informative report emphasizes, for each oiled seabird found in Newfoundland one can assume that at least 10 more have died.

Together with several individuals devoted to the issue of marine oil pollution, author Dr. F. Wiese studied seabirds and their oil-related mortality for many years. His report on chronic offshore oil pollution is structured in two parts: The Problem (11 chapters) and The Solution (8 chapters); four appendices, a list of abbreviations, and some references are also given. Half of the report deals with OSIRs (Oil Spill Intelligence Reports 19972000), presented in Appendix 4. OSIRs are only accessible for a few signed-up members, and it is great that Wiese's report provides the wider public with an opportunity to access this information. Besides reporting baseline numbers of seabird mortalities and oil pollution incidents, other highlights of this document are presented to a wide audience dealing with ocean modelling, detectabilities of oiled birds on a beach, drift block experiments and emphasizing how important such methods are to address the chronic offshore oil pollution efficiently and in accurate terms.

"Most of those in the marine industry carry out their operations in a safe and environmentally responsible manner." This statement is somewhat in contrast to the fact that oiled birds keep washing up on shorelines worldwide which suggests that national legislation and international conventions and guidelines are not being followed or that they are inefficient. "The illegal discharge of oil from ships into the world's oceans is a global problem that affects the entire marine ecosystem". This calls for a well-designed global oiled bird survey; e.g., citizen- and volunteer-based marine and beach surveys.

From this nice report it becomes quickly obvious that the history and track-record of chronic oil pollution, a 
by-product of the current civilisation, is not an environmental success story. Instead, the current progress for trying to keep the (marine) environment clean presents more of an international embarrassment. It is still difficult to understand why the "burden of proof" for chronic oil pollution is not on the industry side. After reading this report and its seabird facts one cannot deny that oil pollution equals environmental massmurder.

It is correct that the Canadian legislation extends the enforcement of shipping, environmental, and wildlife law to the 200-mile exclusive economic zone. However, some federal legal decisions have restricted these laws to the 12-nautical-mile territorial zone. Offshore pollution monitoring flights are made by Transport Canada and by the Canadian Coastguard; the Department of National Defence and Department of Fisheries and Oceans are encouraged as well. Although the Canadian Shipping Act, the Migratory Bird Convention Act, the Canadian Environmental Protection Act, and the Fisheries Act deal with oil pollution issues, suspected ships have rarely been turned back to a Canadian port for further investigations. Only the Migratory Bird Convention Act protects migratory seabirds from oil-related offences; but so far, only five vessels have been charged. Knowing that approximately 2500 offshore oil spills are reported per year in Atlantic Canada, one gets quickly an idea of the issue. Obviously, pollution pays ... and as the report convincingly shows, the pollutor gets almost rewarded due to the competitive business advantage when not punished. Atlantic Canada is simply the cheapest place to dump bilge oil on the Great Circle route between North America and Europe. No doubt, the enforcement needs to be stronger in Canada, higher fines are required, and on board disposal facilities, increased monitoring, increased awareness, and other measures are necessary. Even the European Union uses RADARDSAT (SAR), a satellite image product from Canada, in order to trace and to monitor offshore oil pollution.

As Wiese's WWF report presents, Canada does not really have a national standard for an EDA (Environmental Damage Assessment). It is surprising that the exact number on "how many seabirds are really oiled" is hard to get and not available with high accuracy; accurate numbers seem not to play a role in the legal decision and discussion even! Perhaps court fines should consider a price per oiled seabird, and thus could change the current dilemma?!

This document reports that approximately 40 million pelagic seabirds reside during the year on the
Grand Banks off Newfoundland. However, some of the presented numbers are puzzling and might cause confusion for the informed naturalist. It was reported earlier that over 200000 thick-billed Murres are killed annually during the Murre hunt off Newfoundland. But even now, with chronic oil pollution added, breeding Thick-billed Murres in the Canadian Arctic (the seabird species believed to be affected the most by chronic oil pollution) do not show a significantly declining population trend. Are Canadian seabirds really sensitive indicators of the marine environment? Or are birds from other areas present in Canadian waters, such as Greenland's Thick-billed Murres and Manx Shearwaters from England (both populations are known to be declining), better indicators? More research is required. Some other confusion might arise from the presented population numbers of wintering Eastern Harlequin Ducks, and that no direct relationship is known to exist between the amount of oil spilled and the numbers of seabirds killed. For my taste, some key references such as J. Burger's 1997 book Oil Spills would have been a great addition. Of interest might also be the other Canadian seabird oil pollution work in British Columbia by A. Burger, the Festucca Oil Spill Trust Fund, and the Provincial Government. Globally speaking, it might be interesting for the reader to learn how Norway, a country with major offshore oil resources with a very long coastline and huge seabird resources, deals with chronic oil pollution! Perhaps it would also be informative to have a list of all known oil vessel accidents in Canadian waters.

This informative report provides many important details and baseline information on the sligthly overlooked but very relevant chronic oil pollution topic in the offshore waters of Eastern Canada. It focuses on seabirds; but many other species and the entire ecosystem suffer from oil pollution, too. "Chronic oil pollution is an international problem whose solution requires national and international effort".

\section{FALK HuEtTManN}

Department of Geography-Earth Science, 2500 University Drive N.W., Calgary University, Calgary, Alberta T2N 1N4 Canada

Present address: Biology and Wildlife Department, Institute of Arctic Biology, University of Alaska, Fairbanks, Alaska 99775-700 USA 